\title{
Tax Collection Constraints, and Tax Burden on the Urban Informal Sector Enterprises: Evidence from Bulawayo, Zimbabwe
}

\author{
Mike Nyamazana Sikwila \\ Chinhoyi University of Technology \\ Email: msikwila01@gmail.com
}

Godwell Karedza

Chinhoyi University of Technology

Aldous Mungadza

Zimbabwe Revenue Authority

Doi:10.5901/mjss.2016.v7n6p79

\begin{abstract}
The paper examines the difficulty related to tax collection from the poor informal sector in Bulawayo, Zimbabwe between 2000 and 2014. In the period under review, many formal enterprises closed leading to employee lay-offs and increased unemployment. The unemployed resorted to the informal sector which has grown to be a large proportion of the working population. In order to increase tax base the revenue authority introduced a Presumptive Tax Policy. However, it has been difficult to enforce the policy due to non-compliance by poor informal traders. We carry out a survey of the Bulawayo Metropolitan Province in an effort to unravel the practical challenges of enforcement of the Presumptive Tax to a sector that can hardly cope with the basic needs. The results show that size and number of the informal sector, resource constraints, political interference, corruption tendencies, notions of fairness and tax educational gap influence tax collection in BulawayoZimbabwe. Furthermore, findings from the survey indicate that the low incomes generated by the informal sector persuade them to avoid tax. To date scant research has been done on tax collection and evasion by informal sector in Bulawayo, Zimbabwe. In that regard the study contributes to current literature on the informal sector; also the study adds value to policy making. The research findings of the study are important to government policymakers, urban planners and informal traders' development.
\end{abstract}

Keywords: Informal sector, Taxation, Taxation, Bulawayo, in-migration

\section{Introduction}

In the period between 1980 and 2000 the Zimbabwe tax authorities received tax revenues largely from the formal sector. The tax from the formal sector included individual employee tax, excise duty and import tax on imported goods and services, corporate tax, profits, and value added tax, among others (ZimStats, 2014). However, in the period between 2001 and 2014 the formal sector shrunk leading to reduction in government revenues from taxation. We define the informal sector as traders, vendors or economic activities that are unregistered (see, for example, Schneider,1994a; Frey and Werner, 1984; Lubell, 1991, Todaro, 1969) as per companies Act (Chapter 24:03) and thereby avoid paying tax. The size of the informal sector in Zimbabwe's urban areas has grown over the last four decades from 1980 through to 2014. The influx into urban areas was largely a result of the following: people moving from rural areas into urban areas in search of employment, the population growth that exceeds the economic growth (Potts, 2000), company closure that led to employee layoffs from the formal sector, a rise in unemployment from $11 \%$ in 1982 to 22\% in 1992 and 30\% in 1995 (ZimStats, 2014). The unemployment rate continued to rise in the 2000s with 37\% in 2004 and remained high above 50\% by 2013 , further compounding the size of the informal sector. Despite the large size of the informal sector in Zimbabwe compared to the formal sector (Potts, 2000), its recognition as the largest employer has received little respect from the city authorities and government. Most often the authorities run battles (Tawodzera, 2012) with the informal sector in an effort to remove them from the central business district. We deal with a specific urban area in Zimbabwe that was once the hub of formal business activity, but has since been reduced largely to an informal sector with respect to employment, 
Bulawayo, Zimbabwe. In Bulawayo the majority of people formerly employed in the formal sector are now absorbed by the informal sector. Initially at the dawn of independence in 1980, the informal sector was largely given birth by the influx of the rural migrants into the urban areas who came in search of job opportunities which were scarce. However, the informal sector which was and still is easy to enter and exit (Teilhet-Waldorfs and Waldor, 1983) provided the opportunity to make or raise income.

The informal sector slowly increased in size in the 1980s and 1990s (Tawodzera, 2012; Schneider \& Enste, 2000) and its growth has flummoxed the government that need to collect tax from the sector yet they are clueless on how to do it since they never expected the sector to be a major source of employment in the long term. However, the hyperinflation that set in between 2000 and 2008 (Sikwila, 2013) saw an increase in the informal sector. The closure of companies left a large number of workers with little alternative, but to enter into the informal sector. The closures of companies in the formal sector following Economic Structural Adjustment program (Magure, 2014; Tawodzera, 2012) and the subsequent build-up of the underground economy implied a reduced revenue collection base for the government leading to poor delivery of public goods and services. It is against this background and context that the government sought to expand its tax base by including the poor informal sector in the tax group (presumptive tax Act Chapter 23:06). But the authorities face a problem of incapacity to pay tax by the poor and collection of tax from the unregistered informal sector

To address the collection of revenue from the Informal sector, the Zimbabwe Revenue authority (ZIMRA) employed the Presumptive Tax Policy (Act Chapter 23:06). (GOZ, 2005). The introduction of the Presumptive tax legislation in Zimbabwe is an effort to widen the revenue base in view of the increase in informal business activities in the country. As has been already mentioned, the collection of tax from the unregistered low income informal sector has been a problem for the authorities in Zimbabwe. The problem is that the informal sector employment incomes are relatively low to subsistence level; subsequently the participants in the informal sector avoid payment of taxes. The overall purpose of this study is to explore how the informal business sector in Zimbabwe can leverage on its economic ability (incomes) to contribute to the Government tax revenue. The main objective is to establish the constraints that hinder incorporation of the informal sector enterprises into the tax base. The main question that has not been answered in the literature and Zimbabwe in particular is why does the informal sector evade paying tax? The rationale is that by focusing on the informal sector employment tax evasion in the Bulawayo metropolitan urban area we illuminate wider issues of unemployment, poverty and equity policy in the less developed countries. Also the study sheds light to policy makers regarding the difficulty in collecting tax from poor urban informal sector (Potts, 1995; Magure, 2014)

The current literature stresses the importance of both the informal and formal sectors importance in terms of employment (Brand, 1986). Also, the literature looks at the informal sector with respect to industrial development or economic growth and urban in-migration labour absorption (Merrick, 1976; Potts, 2000). The point of departure in this study is that the informal sector is perceived by tax authorities in Zimbabwe as a source of revenue although the government does not support its growth towards its graduation into the formal sector as explained in a report by International Labour Organization (ILO, 1972) on Kenya and Melitz (2005). Furthermore, previous studies cover how the informal sector has grown and the causes of its growth. Also, the conditions under which the informal sector operated over years have been discussed in the current studies (See, for example, Tipple, 2005; Potts, 1995; Brand, 1986; Kanji \& Jazdowska, 1993). In addition, recent studies cover urban environment in terms of physical and health aspects (Potts, 2008). But little research has been done with regard to taxation of the poor informal sector in developing countries in SubSaharan Africa

It is against this background that a survey of the informal sector in the Central business district (CBD) of Bulawayo was carried out during the course of January to February 2015. A mixed research method was used to collect quantitative and qualitative primary data from the Bulawayo urban informal sector regarding their income and ability to pay tax. The study collected primary data using self completing questionnaire and face to face interviews as the main instruments using a mixture of nominal and likert scale of measurement. The SPSS-Version 21 was used to analyse the data. The results show that size and number of the informal sector, resource constraints, political interference, corruption tendencies, notions of fairness and tax educational gap influence tax collection in Bulawayo, Zimbabwe.

According to our observations very scant research has been undertaken regarding the potential of informal sector contribution and ability to pay tax in Zimbabwe. The recognition that the informal sector can be expected to play a critical role in government revenue has been lacking in recent less developed studies. Subsequently, this study contributes to the body of informal sector literature by exploring the feasibility of tax collection in practice from the poor informal sector employment, in Bulawayo, Zimbabwe. The article is divided into five sections. Section One presents the introduction and explains the premise and context under which the poor urban are required to pay tax, Section Two discusses existing literature, Section Three presents the methodology, Section Four presents the discussion and Section Five gives the conclusion and recommendation. 


\section{Literature Review}

Theories of the informal sector have been developed over decades see for example: Lewis (1954); Todaro (1969); Singer, (1970); ILO (1972); Hart (1973); Piore and Sabel (1984); Portes, Castetells and Benton (1984); and Chen (2012). But all seem to explain the factors that have led to the expansion of the informal sector in both developed and less developed countries (Gerxhani, 2004). In studies by Potts (2008); ILO (1972) and Brand (1986) it is noted that in the SubSaharan Africa the informal sector is an essential source of employment. Brand (1986) carried out a study in Magaba, Harare, Zimbabwe and concluded that the rural immigrants were absorbed in the informal sector. Brand (1986) found that the immigrants were involved in various sectors such as textiles, motor industry, food industry, repair and maintenance, small scale production economic activities and petty trading in a variety of products. The informal traders were able to earn subsistence income (Brand, 1986) for their families. However, the informal sector faces the problem of trading premises and permanent shelter. This led to difficulties in locating them (Brand, 1986) in that they would shift from place to place. The workplace of the informal traders included footpaths, roadside and robots, shop pavements, home-based enterprises and rented places. The informal sector was considered at the time (Brand, 1986) by tax authorities to be earning relatively insignificant incomes to warrant taxation.

In a similar study to Brand's (1986), Tipple (2005) has carried out a survey of the home based enterprises (HBE) in the informal sector in Cochabamba, New Delhi, India; Surabaya, Indonesia and Pretoria, South Africa and found that HBE characteristics were similar to the informal sector operating outside homes. The HBE exhibited low incomes compared to formal sector (Tipple, 2005), but the income was critical in that it had a positive impact in ameliorating the grip of poverty. The HBE were difficult to identify by tax officials, and thereby making it possible for them to evade tax collection.

Potts (2008) has explained that the dualism concept that viewed the informal sector as backward and unable to contribute to economic growth and development meant that governments were not in favour of informal sector expansion. The characteristics of the informal sector, among other things, were that of low productivity with little income (ILO, 1972) that was insignificant and therefore not considered for taxation purposes. Despite the ever increasing number of the unemployed and the inevitable expansion of the informal sector no efforts were done to recognise them or assist them. In effect, these people were not considered in the authorities plans for taxations. The lack of registration made it difficult to include the people whose economic activities were under ground and very active (ILO, 1972; Potts, 2008), but illegal in the eyes of governments. Thus, the informal sector in the 1980 s through to 2000 was viewed by policy-makers as undesirable sector that distorted the labour and product formal markets.

In a report by International Labour Organization (ILO, 1972) on Kenya when the informal concept was coined by the organization, over four decades ago it was indicated that the informal sector was ideal for improving incomes of unemployed population in the urban areas. The projects or economic activities undertaken in the informal sector require little capital in terms of funds and equipment to start. Also, the informal sector used the indigenous inputs or domestic capital to start and run their businesses (Potts, 2008). In a study of urban migration and unemployment, Potts (2000) found that urban economies have declined between 1990 and 2000 period in Harare, Zimbabwe. Potts (2000) explains that in the 1990s policies such as ESAP led to unemployment in that many companies retrenched workers in an effort to align themselves with ESAP policy measures (Tevera, 1995). Potts (2000) has argued that the economic decline between 1990 and 2000 in Harare, Zimbabwe, narrowed the gap between the rural and urban incomes. The net in-migration into the urban areas should decline as it became difficult to raise incomes in urban areas due to closure of companies and the emergence of informal employment. The population movement from urban areas did not amount to circular migration (Potts, 2000; Kanji, and Jazdowska, 1993), particularly for Zimbabwe in that in the early 2000s, urban population moved out of the country to seek better incomes in other countries, rather than go back into the rural areas (circular migration, Potts, 2000:907). The urban population that moved to rural areas were taking advantage of land redistribution that took place in the period 2000 and onward. The informal sector employment provide subsistence income for lower income (Merrick, 1976:342) and also moonlighting done by civil service workers and educational sectors whose incomes do not meet basic needs. Magure's (2014) study of the informal sector in Chegutu in 2010 found that the incomes earned in the informal sector were low. Magure (2014) has noted that in most cases traders sold similar products, thereby creating a market glut leading to poor sales and incomes.

Studies have shown that higher tax rates tend to impel formal businesses into underground economy (Kaufmann, 1997). However, in a study of 69 countries Friendman, et al.,(2000) found that on the contrary over-regulation and corruption persuaded businesses to move to the informal sector, and thereby avoid paying tax. Also, weak institutions and management led to low tax revenue as a percent of gross domestic product (Friendman, et al., 2000). If marginal tax rates are high firms are persuaded to move from formal to informal sector (Gordon and Li, 2009) where cash transactions 
are the order of the day, and thereby avoid taxation. Gordon and Li (2009) explain that the use of banks in developing countries might assist governments in enforcing tax payment from the informal sector. However, the idea does not work in less developed countries because of relatively low interest rates and higher bank charges that discourage the use of commercial banks.

Schneider and Enste (2000) have carried out a comprehensive survey of the informal economy in Africa, Latin America, Asia and OECD countries in an effort to measure the size, causes and influence of the informal sector on the formal economy. Schneider and Enste (2000) found that in Africa the size of informal sector as percent of Gross domestic product (GDP) average between 1990 and 1993 in Nigeria and Egypt was 68 - 76\%, while in Tunisia and Morocco was $39-45 \%$ of GDP. The increase in the informal sector over the last four decades was due to unemployment, burden of higher marginal tax rate, government regulations, social security systems and corruption (Schneider and Enste (2000). However, the assessment of the impact of increasing informal sector in Africa, Asia, Latin America and OECD countries was not conclusive (Schneider and Enste, 2000). The corruption factor was present in all regions and its effect persuaded companies to move into the informal sector. In fact, corruption was positively correlated with an increase/decrease in the level of informal sector in any given economy. Thus, corruption epitomizes a dysfunctional system that forces firms and individuals to join the informal sector. Thus, it is expected that a corrupt country should experience a large size of informal sector relative to formal economy (Schneider and Enste, 2000) and a less corrupt country has a small informal sector.

The work of Mankiw, at al., (2009) explores the dependence of policymakers on optimal tax theory prescriptions. The tax aspects that tend to link tax theory with tax policy are in the branch of capital income tax (Mankiw, at al., 2009) that has reduced over the years. Also the trends globally appear to favour a flat tax rate for similar incomes. However, there are other issues that are not covered by tax theory such as ability to pay and equity aspects. Teilhet-Waldorfs and Waldor (1980) used participant observation method to examine self-employed workers in three categories that included vendors, brick workers and shopkeepers in the informal sector of Bangkok. Teilhet-Waldorfs and Waldor (1980) found that the informal sector in their sample had higher income earnings compared to unskilled workers in the informal sector. As Teilhet-Waldorfs and Waldor notes, the majority of the participants had left the informal sector, perhaps, because of poor wages relative to their skills or tried to avoid taxation from their low incomes. Bigsten, Kimuyu and Lundvall (2009) have argued that Kenya ought to follow a policy that will attract the informal sector firms to join the formal in the long term. However, incentives and benefits that would persuade the informal enterprises to register were lacking in Kenya (Bigsten, Kimuyu and Lundvall, 2009).

\section{Methodology}

As has been previously mentioned, the aspects that led to unemployment and expansion of the informal sector in urban areas include; rural net in-migration and company closures due to ESAP (Potts, 2000). In effect these aspects led to low levels of government revenue from taxation. The aspects mentioned above provide the premise and/or context within which the tax authorities desire to collect tax from the informal sector (Potts, 2000; Melo, 1999). In an attempt to investigate the tax collection and subsequent avoidance from the informal sector a survey of the informal sector in Bulawayo - Zimbabwe was carried out in the course of January to February 2014. The businesses were classified as informal sector (nominal scale) if they were not registered with the companies Act (Chapter 24:03) and operated on a permanent shelter or building. A cross-sectional study design was chosen, its choice was justified because the informal sector covered a cross-section of industries and economic sectors. A mixed research methodology was used to collect quantitative and qualitative primary data from the Bulawayo urban informal sector regarding their income and ability to pay tax. The location of the study was in Bulawayo central business district (CBD) and its surrounding areas peripheral to the city, and in the neighbourhood of the high density or low income dwelling with respect to population. The researchers explained the purpose and relevance of the study to the informants to entice co-operation. The study collected primary data using self completing questionnaire and face to face unstructured interviews as the main instruments using a mixture of nominal and likert scale of measurement. Both open and closed questions were employed in an attempt to obtain indepth information regarding tax inversion and ability to pay by businesses in the informal sector in Bulawayo urban area. A pilot study was conducted and questions that were not clear to the respondents were adjusted in order to obtain accurate information. In the absence of a sampling frame a non-probability sample was adopted. The researchers used a combination of purposive sampling and non-participant observation to choose respondents to be interviewed from the urban informal sector in Bulawayo. This approach was justified in that by closely observing informants in-depth information and data was obtained particularly on daily, monthly and annual sales and profits that epitomise incomes of the informal sector. The respondents were asked about their personal history, personal characteristics, estimates of their revenues and expenditures starter up capital and incomes, ages and training, among other things. A sample of 250 
respondents was chosen from a cross-section of sectors that included: textiles, metal and metal products, chemicals, foot wear, furniture, motor, electrical, mining and agricultural products, among others. The SPSS-Version 21 was used to analyse the quantitative data and the qualitative data was analysed through a narrative approach using information obtained from the key informants. The response rate was $87 \%$ which reflected the interest of the respondents in the questions posed to them.

\section{Results and Discussion}

The study indicates that in an effort to collect tax from the informal sector the authorities faced problems which include: size and number of the informal sector, resource constraints, political interference, corruption tendencies, notions of fairness and tax educational gap (see, figure 1). Size and number of informal sector: The sheer size and increase of the informal sector presents huge constraints for the authorities in that it was difficult to cover all of them, thereby making it easier to avoid taxation. Figure 1 show that from the total constraints the size and number of the informal sector presented $20 \%$ of the constraints faced by the authorities. The resource constraints: that include physical, financial and human capital make sense when one takes into account that the informal sector are not confined to a particular location.

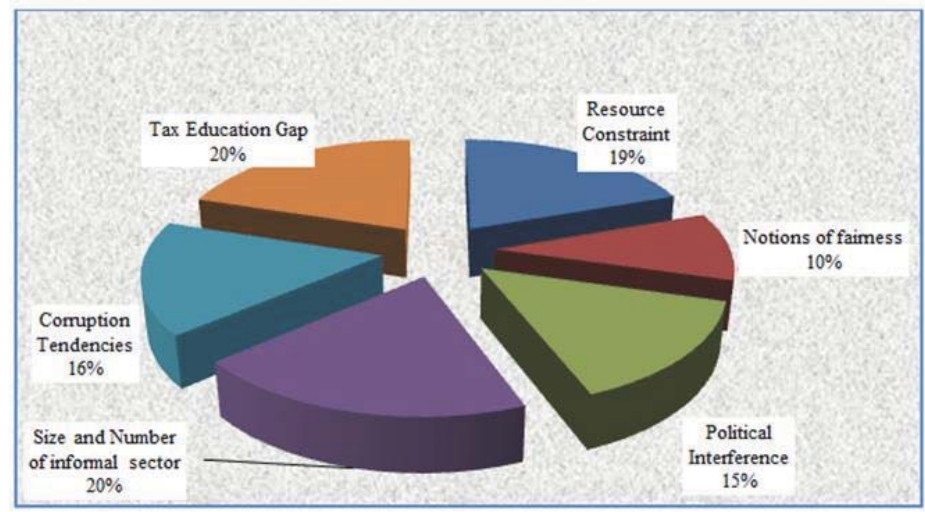

Figure 1: Constraints in Collecting Tax from Informal Traders

Source: Researcher Data

The resource constraint variable covers 19\% of total constraints. In fact, the risk that the authorities faced was that the cost of pursuing the informal sector tax payers could exceed the revenue collected from the sector. The political interference and corruption tendencies are other constraints that curtail tax collection from the informal sector. This finding supports work by Schneider and Enste (2000) who report a positive correlation of corruption and an increase in the informal sector that avoided taxation. Thus, if officials are corrupt it will be difficult to collect tax from the informal sector in that the tax payer believes the money paid was not for the government. Because corrupt officials are expected to have a tendency to seek rent from would-be tax payers in the absence of a strong institutional arrangement. Political interference was justified by the need to obtain votes in times of elections and it covers $15 \%$ of the constraint spectrum, while corruption covers $16 \%$ of the total constraints. Tax education gap forms $20 \%$ implying that the informal sector needs to be educated on the advantages of paying tax to revenue authorities. The notions of fairness constraints represent $10 \%$ of the total constraints. Also, the idea of equity and farness ought to be explained to the informal sector in that these issues influenced tax avoidance. On discussion with some of the informal sector informants it was revealed that the informal sector was willing to partake in revenue contribution, but inconsistent low incomes negatively affected their survival and persuaded them to avoid tax. In addition, the high marginal tax rates in some cases lump sum tax for those in transport prevented the informal businesses to comply with tax laws. The study suggests that lower marginal tax rates are expected to persuade many informal businesses to comply and pay tax. The compliance would lead to a broader tax base and an increase in government revenue. 


\section{Conclusion and Recommendation}

In the article we examine the constraints that inhibit the collection of tax revenue from the informal sector in Bulawayo, Zimbabwe. The informal sector has expanded in Zimbabwe between 2000 and 2014, while the formal sector has shrunk. To increase its tax revenue the tax authorities have resorted to the informal sector. However, the tax avoidance by the poor urban informal sector has caused problems for the tax authorities in Zimbabwe. In the current studies, scant research has been undertaken to reveal the constraints that prevent the poor urban informal sector from paying the much needed tax that ought to assist in improving social services in the country. The present study revealed and presented the constraints that inhibited the informal sector from paying tax. It was expected that the new information ought to improve tax policy formulation, leading to enhanced tax collection. In an effort to increase its tax base and collect more tax from the informal sector the authorities have introduced a presumptive tax Act (Chapter 23:06). Nevertheless, this tax policy has not improved revenue collection from the informal urban enterprises. It was in this context that we carried out a crosssectional study and interviewed the informal sector in Bulawayo, Zimbabwe between January and February 2014. The SPSS-Version 21 was used to analyse the qualitative and quantitative data. The results of the study suggests that tax collection was influenced by size and number of the informal sector, resource constraints, political interference, corruption tendencies, notions of fairness and tax educational gap. It was also revealed by informants that the ability to pay and issues of equity persuaded them to avoid tax. It is recommended that a lower marginal tax rate and a strengthening of institutional arrangements ought to improve tax collection from the informal sector in Bulawayo, Zimbabwe.

\section{References}

Bigsten, A., Kimuyu, p \& Lundvall. (2009). what to do with the informal sector? Development Policy Review, 22(6), 701-715.

Brand, V. (1986). One Dollar Workplaces: A Study of Informal Sector Activities in Magaba, Harare. Journal of Social Development in Africa, 1, 53-74.

Chen, M. A. (2012). The informal economy: Definitions, Theories and policies, Women in informal employment globalizing and organizing: Wlego working paper No. 1 (August 2012): 1-22

Frey, B. S. \& Werner, P. (1984). The Hidden Economy: state and prospect for measurement. Review Income Wealth, 30(1), 1-23.

Gerxhani, K. (2004). The informal sector in developed and less developed countries: A literature survey. Public Choice, 120: 267-300.

Gordon, R. \& Li., W. (2009). Tax structure in developing countries: Many puzzles and a possible explanation. Journal of Public Economics, 95, 855-866.

Hart K (1973). Informal Income Opportunities and Urban Employment in Ghana. Journal of Modern African Studies, Vol. 11(1).

International Labour Office. (1972). Employment, Income and Equality: a strategy for increasing productive employment in Kenya. UNDP/ILO, and Geneva: ILO.

Kanji, N. \& Jazdowska, N. (1993). Structural Adjustment and the Implications for Low-income Urban Woman in Zimbabwe. Review of African Political Economy 56: 11-26.

Kaufmann, D. (1997). The missing pillar of a growth strategy for Ukraine. In: Cornelius P Lenain P. (Eds) Ukraine: Accelerating the Transition to market. IMF, Washington DC.

La Porta, R. Lopez-de-Silanes, F., Shleifer, A., Vishny, R. W. (1999). The quality of government. Journal of Law, Economics and organization, 15(1), 222-279.

Lewis, W. A. (1954). Economic Development with unlimited Supplies of labour. Manchester School of Economics and social studies 22: 139-91.

Lubell, H. (1991). The Informal Sector in the 1980's and 1990's. Paris: OECD.

Magure, B. (2014). Interpreting Urban Informality in Chegutu, Zimbabwe. Journal of Asian and African Studies, 1-17.

Mankiw, N. G. Weinzierl, M. C \& Yagan, D. F. (2009). optimal taxation in theory and practice. Journal of Economic Perspectives, 23(4): 147-174.

Melitz, M. (2005). When and how should infant industries be protected? Journal of International Economics, 66, 177-196.

Melo, M. (1999). Fiscal Crisis, Globalization and urban Development: The politics of Exclusion in Brazil 1980-98, Paper presented at South-to-South Conference, London, ICS (March).

Merrick, T.W. (1976). Employment and Earnings in the Informal Sector in Brazil: The case of Belo Horizonte. The Journal of Developing Areas, Vol. 10(3): 337-354.

Piore M \& Sabel, C. (1984). The second Industrial Divide. New York: Basic Books.

Portes, A. Castells, M. \& Benton, L. A. eds (1989). The Informal Economy: Studies in Advanced and Less Developed Countries. Baltimore, MD. USA: John Hopkins University Press.

Potts, D. (1995). Shall we go home? Increasing Urban Poverty in African Cities and Migration Processes. The Geographical Journal Vol. 161(3): 245-264.

Potts, D. (2008). The urban informal sector in Sub-Saharan Africa: from bad to good (and back again?). Development Southern Africa, Vol. 25(2), 151-167.

Potts, D. \& Mutambirwa, C. C. (1998). "Basics are now a Luxury": Perception of ESAP's Impact on Rural and Urban Areas in Zimbabwe, 
Environment and Urbanization (special issue, Beyond the Rural and Urban Divide) 10(1): 55-76.

Schneider, F. \& Enste, D. H. (2000). Shadow Economics: Size, Causes, and Consequences. Journal of Economic Literature, Vol. XXXVIII, 77-114.

Schneider, F. (1994a). Measuring the size and development of the shadow economy: can the causes be found and the Obstacles be overcome? In Hermann Brandstaetter and Werner Guth: Springer: 193-212.

Sikwila, M. N. (2013) Dollarization and the Zimbabwe's Economy. Journal of Economics and behavioral Studies. Vol. 5(6), 398-405.

Singer, H. W. (1970). Dualism Revisited: A New Approach to the problems of Dual Society in Developing Countries. Journal of Development Studies, vol. 7(1).

Tawodzera, G. (2012). Urban Household Survival and Resilience to Food Insecurity in Crisis Conditions: The case of Epworth in Harare, Zimbabwe. Journal of Hunger and Environment Nutrition, 7: 293-320.

Teilhet-Waldorf S. \& Waldorf, W. H. (1983). Earnings of Self-employed in an informal sector: A case study of Bangkok. Economic Development and Cultural Change, vol. 31(3), 587-607.

Tevera, D. (1995). The Medicine that Might Kill the Patient: Structural Adjustment and Urban Poverty in Zimbabwe, in D. Simon et al, (eds) Structurally Adjusted Africa, pp. 79-90. London: Pluto Press.

Tipple, G. (2005). The Place of Home-based Enterprises in the Informal Sector: Evidence from Cochabamba, New Delhi, Surabaya and Pretoria. Urban Studies, Vol. 42(4), 611-632).

Todaro, M. P. (1969). A model of labour migration and urban unemployment in less developed countries. American Economic Review, 59: $138-48$.

ZimStats, (2014). Quarterly Digest of Statistics, Government of Zimbabwe, Harare. 
ISSN 2039-2117 (online)

ISSN 2039-9340 (print)
Mediterranean Journal of Social Sciences MCSER Publishing, Rome-Italy
Vol 7 No 6 November 2016 